\title{
Alternative Products to Control Soybean Downy Mildew in the Field
}

\author{
Gislaine Gabardo ${ }^{1}$, Maristella Dalla Pria ${ }^{2}$, Henrique Luis da Silva ${ }^{3} \&$ Mônica Gabrielle Harms ${ }^{1}$ \\ ${ }^{1}$ Post Graduate Program in Agronomy, State University of Ponta Grossa, Ponta Grossa, PR, Brazil \\ ${ }^{2}$ Agronomy Department, State University of Ponta Grossa, Ponta Grossa, PR, Brazil \\ ${ }^{3}$ Science and Technology Analyst, Rural Development Institute of Paraná, Ponta Grossa, PR, Brazil \\ Correspondence: Gislaine Gabardo, Post Graduate Program in Agronomy, State University of Ponta Grossa, \\ General Carlos Cavalcanti Street, 4748, 84030-900, Uvaranas, Ponta Grossa, Paraná, Brazil. Tel: \\ 55-42-3220-3738. E-mail: gislainegabardo2007@yahoo.com.br
}

Received: May 19, 2020

doi:10.5539/jas.v12n8p160
Accepted: June 22, $2020 \quad$ Online Published: July 15, 2020

URL: https://doi.org/10.5539/jas.v12n8p160

\begin{abstract}
Soybean mildew caused by Oomycota Peronospora manshurica, is a disease widely spread in Brazil. In order to study the efficiency of soybean mildew control due to the application of alternative products and fungicide in the field, experiments were conducted in Ponta Grossa, PR, Brazil, during the 2013/2014 and 2014/2015 growing seasons. The design used was randomized blocks with four replications. The treatments were: 1-witness; 2-acibenzolar-S-methyl; 3-calcium; 4-micronutrients: copper, manganese and zinc; 5-micronutrients: manganese, zinc and molybdenum; 6-NK fertilizer; 7-Ascophyllum nodosum and 8-azoxystrobin + cyproconazole with the addition of Nimbus adjuvant. Four applications of alternative products (phenological stages V3, V6, R1 and R5.1) and two of fungicide (phenological stages R1 and R5.1) were performed. The mildew severity was estimated using a diagrammatic scale. The severity data made it possible to calculate the area under the disease progress curve (AUDPC). In the 2014/2015 harvest the disease was more severe. The control of downy mildew by the use of fungicide did not reduce the epidemic. The fungicide was not efficient in the two evaluated seasons. All tested alternative products reduced the disease severity and AUDPC in both seasons. The best results in reducing downy mildew were found with the application of acibenzolar-S-methyl, micronutrients $(\mathrm{Cu}, \mathrm{Mn}, \mathrm{Zn})$ and $A$. nodosum.
\end{abstract}

Keywords: Ascophyllum nodosum, Glycine max, Peronospora manshurica, control, micronutrients, calcium

\section{Introduction}

Brazil is the world's largest soybean producer (USDA, 2019). Soybean, Glycine max (L.) Merril, is an annual legume of the Fabaceae family. It is the most economically important grain in the world due to its productive potential, chemical composition and nutritional value (Faccin \& Castillo, 2019). Conferring several applications in human and animal food, with relevant socioeconomic role, in addition to be an indispensable raw material to increment several agroindustrial complexes (Callegaro et al., 2018; Thadani \& Rocha, 2019). Among factors limiting crop yield, there is occurrence of diseases.

Approximately 40 diseases caused by fungi, bacteria, nematodes and viruses have already been identified (Hartman et al., 2015). Among these diseases, there is downy mildew, caused by Oomycota Peronospora manshurica (Naumov) Syd. a biotrophic pathogen belonging to the Stramenopila kingdom, Peronosporales order and Peronosporaceae family. Hyphae are cenocytic and sporangiophores are gray or light violet. Sporangia are sub-hyaline, slightly elliptical to subglobous (Dong et al., 2019). The causal agent of downy mildew has cellulose in its cell wall, which is why it is not classified as a fungus (Miranda \& Pires-Zottarelli, 2012).

Downy mildew is a disease widespread in the main soybean producing regions of Brazil and can manifest itself throughout the cycle, occurring more frequently in crops in the south of the country (Fontana et al., 2006). It can cause damage of 8 to $14 \%$ in productivity (Silva et al., 2011). An aggravating factor is that specific control for downy mildew is totally neglected in the cropping, since fungicides used to control the main leaf diseases are not efficient to prevent epidemics of this disease (Kowata et al., 2008). In addition to genetic resistance not being part of breeding programs in Brazil, susceptible cultivars have been widely cultivated. These factors can contribute to losses for Brazilian producers (Silva et al., 2013). 
The control of downy mildew, carried out by the exclusive use of fungicides, has not provided satisfactory results. The use of pesticides can cause damage to the environment, leading to environmental imbalance and selection of fungicide resistant fungal populations, in addition to raising the crop production's cost (Tupich et al., 2017). The reduction or elimination of pesticides in disease control is an economic and environmental necessity (Müller et al., 2019; Thadani \& Rocha, 2019).

Alternative products have a low environmental impact which makes their use in control of plant diseases very attractive (Di Piero \& Garda 2008; Lorencetti et al., 2015). When compared to fungicides, they offer great advantages, such as generation of new compounds, which pathogens are not able to inactivate, that is, to develop resistance. In addition to being less toxic, rapidly degrading in the environment and presenting a broad mode of action (Kobayashi \& Amaral 2018).

However, it can present some disadvantages. Dependence on environmental factors (humidity, light and temperature) and product concentration (Moura et al., 2014). Another disadvantage is the dependence on an interval between the application of the product, the development of the plant's defenses against the pathogen and the need for reapplication (Jackson et al., 2000; Kagale et al., 2004). It may require energy expenditure from the plant (Goel et al., 2018; Lorenzetti et al., 2018).

These products can act in the protection promoted by balanced mineral nutrition, resulting in the formation of an efficient physical barrier, with inhibition of hyphae penetration or better permeability control of the cytoplasmic membrane (Marschner, 1995; Furtado, da Rosa Dorneles, \& Dallagnol, 2020). In addition to the possibility of acting as activators of plant resistance, by stimulating the production of phytoalexins and proteins related to pathogenesis (Jackson et al., 2000; Nawrocka et al., 2018) they can be used in the production of organic soybean.

Demand for organic soybean is increasing, along with society's tendency to seek healthier lifestyle habits (Martinelli \& Cavalli, 2019). Its production is a good investment for small farmers, adding value to their production (Inagaki et al., 2018). However, disease control is the major challenge for this production system (Ibanhes et al., 2019). In this context, the present work aimed to evaluate the effect of foliar application of alternative products on the severity of soybean downy mildew in the field, cultivar BMX Potência RR in the 2013/2014 and 2014/2015 growing seasons.

\section{Method}

Two experiments were conducted in the 2013/2014 and 2014/2015 growing seasons, in the municipality of Ponta Grossa-PR-Brazil, located at $25^{\circ} 13^{\prime} \mathrm{S}$ latitude and $50^{\circ} 03^{\prime} \mathrm{W}$ longitude and $900 \mathrm{~m}$ altitude. The soil at the site is classified as HAPLIC CAMBISSOL Tb Typical Eutrophic, clayey texture (EMBRAPA, 2006). The cultivation system adopted in the area is direct sowing in the straw. The average monthly temperatures, total monthly precipitation and the average humidity in the area of the experiments in the period, were collected by an agrometeorological station located close to the experimental field (Table 1).

The experimental design adopted was randomized blocks, with 8 treatments and four replications, in plots measuring $6.0 \times 4.0 \mathrm{~m}\left(24 \mathrm{~m}^{2}\right)$, with a useful area of $5.0 \times 1.8 \mathrm{~m}\left(9.0 \mathrm{~m}^{2}\right)$. The treatments consisted of foliar application of the products: 1-witness (water); 2-acibenzolar-S-methyl (Bion $\left.500 \mathrm{WG}{ }^{\circledR}\right)\left(25 \mathrm{~g}\right.$ p.c. ha ${ }^{-1}$ ); 3-calcium (Max Fruit $\left.{ }^{\circledR}\right)\left(0.75\right.$ L p.c. ha $\left.^{-1}\right)$; 4-micronutrients: copper, manganese and zinc (Wert Plus $\left.{ }^{\circledR}\right)(0.75$ L p.c. ha $\left.{ }^{-1}\right)$; 5-micronutrients: manganese, zinc and molybdenum (V6®) $\left(0.75 \mathrm{~L} \mathrm{p.c.} \mathrm{ha}^{-1}\right)$; 6-NK fertilizer (Hight Roots $\left.{ }^{\circledR}\right)\left(0.75\right.$ L p.c. ha $\left.{ }^{-1}\right)$; 7-Ascophyllum nodosum alga $\left(\right.$ Acadian $\left.{ }^{\circledR}\right)\left(2.0\right.$ L p.c. ha $\left.{ }^{-1}\right)$ and 8-azoxystrobin + cyproconazole (Priori XTRA®) $\left(300 \mathrm{~mL}\right.$ p.c. $\left.\mathrm{ha}^{-1}\right)$ with the addition of Nimbus adjuvant $(0.5 \% \mathrm{v} / \mathrm{v})$. The development of soybean crop was accompanied by the phenological scale proposed by Ritchie et al. (1997).

In the two experiments, 4 applications of alternative products were carried out in the phenological stages V3 $\left(2^{\text {nd }}\right.$ developed trefoil), V6 ( $5^{\text {th }}$ open trefoil), R1 (beginning of flowering) and R5.1 (grains noticeable to the touch$10 \%$ of grain) and two applications of the fungicide in the phenological stages R1 and R5.1. The applications were carried out using a knapsack sprayers of constant pressure $\left(\mathrm{CO}_{2}\right)$, equipped with a bar with simultaneous arrangement of four flat fan tips (XR 11002) spaced $0.50 \mathrm{~m}$ apart and pressure of $3 \mathrm{~kg} \mathrm{~cm}^{-2}$. A flow rate of $250 \mathrm{~L}$ $\mathrm{ha}^{-1}$ was used for all products. The application was conducted under suitable climatic conditions, relative humidity above $60 \%$ and temperatures below $30^{\circ} \mathrm{C}$.

The soybean cultivar used was BMX Potencia RR, which has a semi-early cycle, an indeterminate growth habit, susceptible to Asian rust (Phakopsora pachyrhizi H. Sydow \& P. Sydow), powdery mildew (Microsphaera diffusa Cooke \& Peck) and downy mildew; resistant to stem canker (Diaporthe phaseolorum f. sp. meridionalis $(\mathrm{Dpm})$ ); moderately resistant to frogeye leaf spot (Cercospora sojina Hara). Sowing was conducted in a direct 
sowing system, on wheat straw, on 12/18/2013 and 12/16/2014, using spacing between rows of $0.45 \mathrm{~m}$ with 15 seeds per meter to obtain density of 12 plants $\mathrm{m}^{-1}$ and final population of 250,000 plants ha ${ }^{-1}$.

The seeds were treated with fipronil + pyraclostrobin + methyl thiophanate (Standak Top - $200 \mathrm{~mL} \mathrm{p.c} 100 \mathrm{Kg}^{-1}$ seed) and inoculated with Bradyrhizobium japonicum (Nitrogen-300 mL p.c $100 \mathrm{Kg}^{-1}$ seed). For the basic fertilization, the NPK fertilizer of the commercial formula 04:08:12 was used in the dosage of $300 \mathrm{~kg} \mathrm{ha}^{-1}$. The emergence started on December 24, 2013 in the first harvest and in the second harvest on December $22,2014$. Weeds and pests control was carried out according to the crops needs.

Table 1. Average temperature $\left({ }^{\circ} \mathrm{C}\right)$, total precipitation $(\mathrm{mm})$ and average humidity $(\%)$ in the months of the experiment with soybean (Glycine max) to control downy mildew (Peronospora manshurica). Ponta Grossa/PR, 2013/2014 and 2014/2015 growing seasons

\begin{tabular}{llllll}
\hline Month & December & January & February & March & April \\
\hline 2013/2014 Growing season & & & & & \\
Average temperature $\left({ }^{\circ} \mathrm{C}\right)$ & 20.9 & 21.7 & 21.7 & 20 & 18.2 \\
Total precipitation $(\mathrm{mm})$ & 149.2 & 262.8 & 137.2 & 164.0 & 93.0 \\
Average humidity $(\%)$ & 82.8 & 83.4 & 82.3 & 87.4 & 85.9 \\
\hline 2014/2015 Growing season & & & & \\
Average temperature $\left({ }^{\circ} \mathrm{C}\right)$ & 20.6 & 22.0 & 20.7 & 19.9 & 18.2 \\
Total precipitation $(\mathrm{mm})$ & 353.4 & 125.6 & 234.8 & 168.5 & 65.8 \\
Average humidity $(\%)$ & 83.5 & 81.9 & 85.4 & 87.9 & 84.1 \\
\hline
\end{tabular}

Note. Data provided by the Basf weather station (Badische Anilin \& Soda Fabrik).

The mildew severity assessments were performed weekly during the soybean cycle in both experiments. Estimating the percentage of leaf tissue with disease symptoms in leaves of 10 plants chosen at random, in the two central lines of each plot. Each plant was evaluated in its lower, middle and upper thirds, and the thirds average used for the grade of the entire plant. Mildew severity was estimated with the aid of a diagrammatic scale by Kowata et al. (2008). Diagrammatic scales are illustrated representations of a series of leaves that show symptoms at different levels of disease severity, standard for comparison (Godoy, Koga, \& Canteri, 2006; Kowata et al., 2008). The evaluation of the mildew severity made it possible to calculate the area under the disease progress curve (AUDPC) according to Shaner and Finney (1977).

The data obtained were subjected to analysis of variance by the $\mathrm{F}$ test, the means when significant were compared by the Scott-Knott test at 5\% probability. The severity data in the individual assessments were transformed into $\arcsin \sqrt{(\mathrm{x}+0.5) / 100}$. The analyses were performed with the aid of the statistical software SASM-Agri (Canteri et al., 2001).

\section{Results}

The disease occurred naturally in both seasons (Figure 1). The first symptoms were observed 23 days after emergence (DAE) in the first harvest (2013/2014), persisting until 57 DAE. In the second harvest (2014/2015) the first symptoms occurred at 30 DAE until 53 DAE. In the 2014/2015 growing season there was a delay in the start of the seven-day epidemic, compared to the first crop, although the disease started later, the severity was greater in all performed evaluations (Figure 1). 


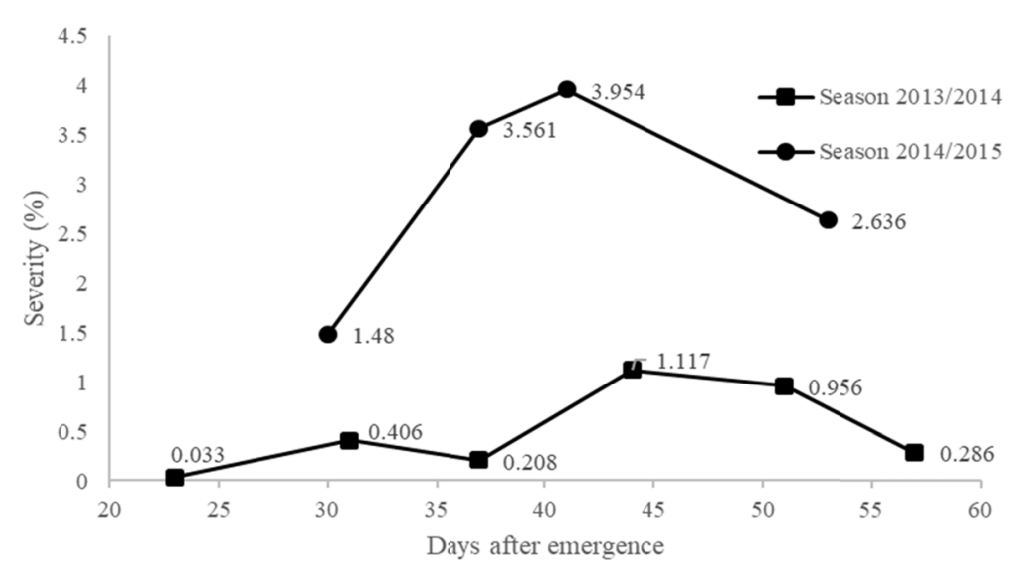

Figure 1. Severity (\%) downy mildew (Peronospora manshurica), depending on the days after the emergence of soybeans (Glycine max), cultivate BMX Potência RR, obtained in the witness (water) in the 2013/2014 and 2014/2015 growing seasons. Ponta Grossa/PR

There were differences between the meteorological conditions that occurred in the two harvests (Table 1). The lower mildew severity occurred in the 2013/2014 growing season, due to weather conditions, which probably disfavored the disease epidemic in this harvest.

In the first harvest, at the beginning of the crop cycle in December and January, precipitation was 149.2 and $262.8 \mathrm{~mm}$ and the temperature was favorable for the fungus development $\left(21.7^{\circ} \mathrm{C}\right)$, but in the following month, in February the precipitation was $137.2 \mathrm{~mm}$ (Table 1). This decrease in precipitation favored the disease occurrence with the advance of the crop cycle, which explains the decrease in the disease severity in February at 44 DAE (Figure 1 and Table 2). Although, in March, the volume of precipitation increased $(164.0 \mathrm{~mm})$, favoring again the pathogen development and the disease progress, which can be observed with the increase in severity (Figure 1).

In the second harvest, the weather conditions were favorable to the epidemic development only from February, since in January the precipitation was low $(125.0 \mathrm{~mm})$ and the average temperature was high $\left(22.0^{\circ} \mathrm{C}\right)$, favoring the disease. In the months of February and March there were the highest volumes of precipitation $(234.8 \mathrm{~mm}$ and $168.5 \mathrm{~mm}$ ), and milder temperatures $\left(20.7\right.$ and $19.9^{\circ} \mathrm{C}$ ) (Table 1), favoring the epidemic. In April, precipitation decreases $(65.8 \mathrm{~mm})$, disfavoring the pathogen, which can be observed with the reduction of disease severity (Figure 1).

In the month of April, there was a reduction in temperature $\left(18.2^{\circ} \mathrm{C}\right.$, in both harvests), in addition to a reduction in precipitation and humidity, disfavoring the disease (Figure 1 and Table 2), with the severity declining from 44 and $41 \mathrm{DAE}$, in the first and second crop, respectively.

Alternative treatments reduced the disease severity. There was a significant difference in the $2^{\text {nd }}, 4^{\text {th }}$ and $5^{\text {th }}$ evaluations (performed respectively at 31, 44 and $51 \mathrm{DAE}$ ), where the severity was lower in the presence of alternative products. In the second harvest, there was a significant difference in all evaluations performed, all alternative treatments used reduced the disease severity. The fungicide did not differ from the witness, both in the first and in the second harvest. The severity values obtained in the first harvest were lower than those obtained in the second harvest. The maximum severity in the first season was $1.12 \%$ in the witness at $44 \mathrm{DAE}$, in the second season it was $3.95 \%$ in the witness at 41 DAE (Table 2). 
Table 2. Severity (\%) of downy mildew (Peronospora manshurica) in different days after emergence (DAE) in the 2013/2014 and 2014/2015 harvests, in different treatments performed on soybeans (Glycine max), cultivar BMX Potência RR, average of the whole plant. Ponta Grossa/PR

\begin{tabular}{|c|c|c|c|c|c|c|}
\hline \multirow{3}{*}{ Treatment } & \multicolumn{6}{|c|}{ 2013/2014 Growing season } \\
\hline & \multicolumn{6}{|c|}{ Severity of downy mildew (\%) } \\
\hline & $23 \mathrm{DAE}$ & $31 \mathrm{DAE}$ & $37 \mathrm{DAE}$ & $44 \mathrm{DAE}$ & $51 \mathrm{DAE}$ & $57 \mathrm{DAE}$ \\
\hline 1-Witness (water) & $0.033 \mathrm{a}^{*}$ & $0.406 \mathrm{a}$ & $0.208 \mathrm{a}$ & $1.117 \mathrm{a}$ & $0.956 \mathrm{a}$ & $0.286 \mathrm{a}$ \\
\hline 2-Acibenzolar-S-methyl & $0.007 \mathrm{a}$ & $0.116 \mathrm{~b}$ & $0.080 \mathrm{a}$ & $0.705 \mathrm{~b}$ & $0.628 \mathrm{~b}$ & $0.201 \mathrm{a}$ \\
\hline 3-Macronutrients: $\mathrm{Ca}$ & $0.010 \mathrm{a}$ & $0.217 \mathrm{~b}$ & $0.096 \mathrm{a}$ & $0.739 \mathrm{~b}$ & $0.718 b$ & $0.170 \mathrm{a}$ \\
\hline 4-Micronutrients: $\mathrm{Cu}, \mathrm{Mn}, \mathrm{Zn}$ & $0.009 \mathrm{a}$ & $0.156 \mathrm{~b}$ & $0.087 \mathrm{a}$ & $0.632 \mathrm{~b}$ & $0.613 \mathrm{~b}$ & $0.215 \mathrm{a}$ \\
\hline 5-Micronutrients: Mn, Zn, Mo & $0.007 \mathrm{a}$ & $0.159 \mathrm{~b}$ & $0.096 \mathrm{a}$ & $0.785 \mathrm{~b}$ & $0.654 \mathrm{~b}$ & $0.221 \mathrm{a}$ \\
\hline 6-NK fertilizer & $0.007 \mathrm{a}$ & $0.262 \mathrm{a}$ & $0.087 \mathrm{a}$ & $0.795 \mathrm{~b}$ & $0.670 \mathrm{~b}$ & $0.189 \mathrm{a}$ \\
\hline 7-Ascophyllum nodosum & $0.013 \mathrm{a}$ & $0.152 \mathrm{~b}$ & $0.084 \mathrm{a}$ & $0.769 \mathrm{~b}$ & $0.554 \mathrm{~b}$ & $0.215 \mathrm{a}$ \\
\hline 8-azoxystrobin + cyproconazole & $0.009 \mathrm{a}$ & $0.336 \mathrm{a}$ & $0.103 \mathrm{a}$ & $0.949 \mathrm{a}$ & $0.888 \mathrm{a}$ & $0.195 \mathrm{a}$ \\
\hline C.V. $(\%)$ & 42.46 & 22.38 & 16.46 & 11.15 & 9.61 & 11.68 \\
\hline \multirow{3}{*}{ Treatment } & \multicolumn{6}{|c|}{ 2014/2015 Growing season } \\
\hline & \multicolumn{6}{|c|}{ Severity of downy mildew (\%) } \\
\hline & \multicolumn{3}{|c|}{$37 \mathrm{DAE}$} & $41 \mathrm{DAE}$ & \multicolumn{2}{|c|}{$53 \mathrm{DAE}$} \\
\hline 1-Witness (water) & $1.480 \mathrm{a}$ & \multicolumn{2}{|c|}{$3.561 \mathrm{a}$} & $3.954 \mathrm{a}$ & \multicolumn{2}{|c|}{$2.636 \mathrm{a}$} \\
\hline 2-Acibenzolar-S-methyl & $0.710 \mathrm{~b}$ & \multicolumn{2}{|c|}{$1.574 \mathrm{~b}$} & $1.896 \mathrm{~b}$ & \multicolumn{2}{|c|}{$0.861 \mathrm{~b}$} \\
\hline 3-Macronutrients: $\mathrm{Ca}$ & $0.658 \mathrm{~b}$ & \multicolumn{2}{|c|}{$1.612 \mathrm{~b}$} & $2.105 \mathrm{~b}$ & \multicolumn{2}{|c|}{$1.005 \mathrm{~b}$} \\
\hline 4-Micronutrients: $\mathrm{Cu}, \mathrm{Mn}, \mathrm{Zn}$ & $0.765 \mathrm{~b}$ & \multicolumn{2}{|c|}{$1.495 \mathrm{~b}$} & $1.705 \mathrm{~b}$ & \multicolumn{2}{|c|}{$0.605 \mathrm{~b}$} \\
\hline 5-Micronutrients: Mn, Zn, Mo & $0.610 \mathrm{~b}$ & \multicolumn{2}{|c|}{$1.775 \mathrm{~b}$} & $1.809 \mathrm{~b}$ & \multicolumn{2}{|c|}{$0.869 \mathrm{~b}$} \\
\hline 6-NK fertilizer & $0.778 \mathrm{~b}$ & \multicolumn{2}{|c|}{$1.541 \mathrm{~b}$} & $1.647 \mathrm{~b}$ & \multicolumn{2}{|c|}{$0.547 \mathrm{~b}$} \\
\hline 7-Ascophyllum nodosum & $0.665 \mathrm{~b}$ & \multicolumn{2}{|c|}{$1.450 \mathrm{~b}$} & $1.515 \mathrm{~b}$ & \multicolumn{2}{|c|}{$0.775 \mathrm{~b}$} \\
\hline 8-azoxystrobin + cyproconazole & $1.415 \mathrm{a}$ & \multicolumn{2}{|c|}{$3.141 \mathrm{a}$} & $3.237 \mathrm{a}$ & \multicolumn{2}{|c|}{$2.137 \mathrm{a}$} \\
\hline C.V. $(\%)$ & 26.95 & \multicolumn{2}{|c|}{30.87} & 21.15 & \multicolumn{2}{|c|}{19.47} \\
\hline
\end{tabular}

Note. *Averages followed by the same lower case letter in the column do not differ by the Scott-Knott test at 5\% significance; original data, for analysis, the data were transformed into $\arcsin \sqrt{(\mathrm{x}+0.5) / 100}$; DAE $=$ days after emergency; C.V. = coefficient of variation.

AUDPC's values obtained in the second harvest were higher than those of the first harvest (Table 3). In the first harvest, the values obtained in the witness were $36.47,14.52,0.98$ and 17.32 for the lower, middle, upper thirds and average of the plant, respectively. In the second harvest, the values obtained were 76.52, 22.80, 4.76 and 34.69 for lower, middle, upper thirds and average of the plant, respectively (Table 3).

There was a difference between the alternative products tested for AUDPC in the two evaluated harvests. In the first harvest (2013/2014) there was a statistical difference both in the lower third and in the whole plant, the treatments acibenzolar-S-methyl (ASM); macronutrient (Ca); micronutrients $(\mathrm{Cu}, \mathrm{Mn}, \mathrm{Zn})$; micronutrients (Mn, $\mathrm{Zn}, \mathrm{Mo}$ ); fertilizer (NK) and A. nodosum reduced the disease severity in relation to witness. However, in the middle and upper thirds there was no statistical difference between the products tested (Table 3).

In the second crop, the application of ASM; macronutrient $(\mathrm{Ca})$; micronutrients $(\mathrm{Cu}, \mathrm{Mn}, \mathrm{Zn})$; micronutrients (Mn, $\mathrm{Zn}, \mathrm{Mo}$ ); fertilizer NK and A. nodosum, reduced the AUDPC in relation to witness both in the lower, middle third and in the entire plant, however, in the upper third there was no difference. In both crops, the fungicide was equivalent to witness (Table 3 ). 
Table 3. Area under the disease progress curve (AUDPG) of downy mildew (Peronospora manshurica) in the lower, middle and upper thirds and average in the whole plant depending on the treatments performed on soybeans (Glycine max), cultivar BMX Potência RR. Ponta Grossa/PR, 2013/2014 and 2014/2015 crops

\begin{tabular}{lllll}
\hline & \multicolumn{4}{c}{ 2013/2014 Growing season } \\
\cline { 2 - 5 } Treatment & AUDPG & AUDPG & AUDPG & AUDPG \\
& Lower third & Middle third & Upper third & Whole plant \\
\hline 1-Witness (water) & $36.47 \mathrm{a}$ * & $14.52 \mathrm{a}$ & $0.98 \mathrm{a}$ & $17.32 \mathrm{a}$ \\
2-Acibenzolar-S-methyl & $20.46 \mathrm{~b}$ & $6.30 \mathrm{a}$ & $0.56 \mathrm{a}$ & $9.16 \mathrm{~b}$ \\
3-Macronutrients: Ca & $25.56 \mathrm{~b}$ & $13.23 \mathrm{a}$ & $0.75 \mathrm{a}$ & $13.19 \mathrm{~b}$ \\
4-Micronutrients: Cu, Mn, Zn & $17.91 \mathrm{~b}$ & $8.73 \mathrm{a}$ & $0.71 \mathrm{a}$ & $9.13 \mathrm{~b}$ \\
5-Micronutrients: Mn, Zn, Mo & $23.07 \mathrm{~b}$ & $10.43 \mathrm{a}$ & $0.72 \mathrm{a}$ & $11.40 \mathrm{~b}$ \\
6-NK fertilizer & $22.40 \mathrm{~b}$ & $13.24 \mathrm{a}$ & $0.36 \mathrm{a}$ & $12.00 \mathrm{~b}$ \\
7-Ascophyllum nodosum & $16.76 \mathrm{~b}$ & $10.62 \mathrm{a}$ & $0.40 \mathrm{a}$ & $9.26 \mathrm{~b}$ \\
8-azoxystrobin + cyproconazole & $32.10 \mathrm{a}$ & $17.87 \mathrm{a}$ & $0.89 \mathrm{a}$ & $16.96 \mathrm{a}$ \\
C.V. (\%) & 34.04 & 35.81 & 44.11 & 30.58 \\
\hline & & $2014 / 2015$ Growing season & AUDPG \\
Treatment & AUDPG & AUDPG & AUDPG & Whole plant \\
\hline 1-Witness (water) & Lower third & Middle third & Upper third & Who \\
2-Acibenzolar-S-methyl & $76.52 \mathrm{a}$ & $22.80 \mathrm{a}$ & $4.76 \mathrm{a}$ & $34.69 \mathrm{a}$ \\
3-Macronutrients: Ca & $29.29 \mathrm{~b}$ & $13.90 \mathrm{~b}$ & $4.33 \mathrm{a}$ & $15.84 \mathrm{~b}$ \\
4-Micronutrients: Cu, Mn, Zn & $29.42 \mathrm{~b}$ & $15.24 \mathrm{~b}$ & $4.67 \mathrm{a}$ & $16.44 \mathrm{~b}$ \\
5-Micronutrients: Mn, Zn, Mo & $26.25 \mathrm{~b}$ & $14.51 \mathrm{~b}$ & $4.30 \mathrm{a}$ & $15.02 \mathrm{~b}$ \\
6-NK fertilizer & $31.69 \mathrm{~b}$ & $14.24 \mathrm{~b}$ & $3.84 \mathrm{a}$ & $16.59 \mathrm{~b}$ \\
7-Ascophyllum nodosum & $28.23 \mathrm{~b}$ & $13.13 \mathrm{~b}$ & $4.15 \mathrm{a}$ & $15.17 \mathrm{~b}$ \\
8-azoxystrobin + cyproconazole & $25.81 \mathrm{~b}$ & $12.50 \mathrm{~b}$ & $3.79 \mathrm{a}$ & $14.03 \mathrm{~b}$ \\
C.V. (\%) & $62.33 \mathrm{a}$ & $23.58 \mathrm{a}$ & $4.60 \mathrm{a}$ & $30.19 \mathrm{a}$ \\
\hline
\end{tabular}

Note. * Averages followed by the same lower case letter in the column do not differ by the Scott-Knott test at $5 \%$ significance; C.V. $=$ coefficient of variation.

\section{Discussion}

The first symptoms of the disease occurred at the beginning of the development of the crop in both season (Figure 1). The disease was more severe in the 2014/2015 crop than in the 2013/2014 crop, this difference is probably due to favorable weather conditions for the pathogen development (Table 1).

Silva et al. (2011) state that the variation in the severity of the disease depends on the region and the climatic conditions of each growing season. Peronospora manshurica is capable of causing damage to the crop when subjected to conditions of high humidity and mild temperatures. The favorable conditions for its development are temperatures between $20^{\circ} \mathrm{C}$ and high humidity, to occur sporulation temperatures between 10 and $25{ }^{\circ} \mathrm{C}$ are necessary, not sporulating at temperatures below $10{ }^{\circ} \mathrm{C}$ and above $30{ }^{\circ} \mathrm{C}$ (Hartman et al., 2015).

Downy mildew is a disease with a very high potential for dissemination (Silva et al., 2011). Zuntini et al. (2019), state that downy mildew occurs in practically all soybean producing regions in Brazil, mainly in the vegetative phase of soybeans, corroborating with the data from the present experiment, since the first symptoms of downy mildew, in the first harvest, occurred at the beginning of the vegetative stage V3 of the crop and the maximum severity $(1.12 \%)$ occurred in the reproductive stage R1. After stage R1 in the fourth evaluation, the disease declined. The disease severity ranged from 0.007 to $1.12 \%$. In 2014/2015, the first symptoms occurred in the V5 stage and the maximum severity occurred in V8 (3.95\%), and at 53 DAE there was a decline in the disease (Figure 1 and Table 2).

Comparing the two harvests, when the severity obtained was low, that is, less than $0.29 \%$, there was no difference in relation to the application of the tested products; however when the severity was greater than $0.29 \%$, all alternative treatments were efficient in reducing the disease severity (Table 2).

With regard to AUDPC, the leaves of the lower third showed higher averages than the leaves of the other thirds of the plant, in all treatments and in both harvests (Table 3). These results can be explained due to the epidemic evolution. Since the disease begins in the unifoliolated leaves and progresses from the leaves from the lower to 
the upper third, reaching the entire aerial part of the plant (Chowdhury et al., 2002), that is, in the middle and upper thirds the disease is developing, which justifies the lower AUDPC values obtained.

Another factor that may justify the higher AUDPC values in the lower third (Table 3), is the difficulty of penetrating product drops into the crop canopy (Tormen et al., 2012), especially of pathogens that initiate the infectious process in the basal leaves, such as mildew. In addition to influencing the products deposition, these characteristics create a microclimate conditions with greater humidity inside the canopy that can favor the occurrence or rapid establishment of the disease (Board, 2001).

With regard to AUDPC of the entire plant, all alternative treatments differed from the witness in both harvests (Table 3). In the first harvest, treatments with ASM, micronutrients $(\mathrm{Cu}, \mathrm{Mn}, \mathrm{Zn})$ and A. nodosum stand out, which reduced AUDPC in the whole plant by 47.11, 47.29 and 46.54\%, respectively. In the second harvest, treatments with ASM, micronutrients $(\mathrm{Cu}, \mathrm{Mn}, \mathrm{Zn})$ and A. nodosum and NK fertilizer reduced AUDPC in the entire plant by $54.34,56.70,59.56$ and $56.27 \%$, respectively.

Silva et al. (2013) in soybean culture using ASM, found that the product significantly reduced the AUDPC of mildew, corroborating the result of this work. In addition, Friedrich et al. (1996) used the same product and were successful in controlling downy mildew (Peronospora hyoscyami f. sp. tabacina (Adam)) in tobacco plants. The ASM used in the experiment is a functional analogue of salicylic acid. According to Klessig, Choi \& unempsey (2018), ASM has no fungistatic action and develops a role similar to salicylic acid in the signal transduction pathway that leads to acquired systemic resistance. Dong et al. (2019) studied the defense mechanisms involved in P. manshurica resistance genes and concluded that these genes encode the induction of salicylic acid.

Host defense induction can also occur due to the presence of macro and micronutrients. Mineral nutrients influence disease resistance, acting in the plant as co-factors of enzymes that participate in several metabolic pathways for plant defense (Vasconcelos et al., 2001; Fageria et al., 2009; Debona, Cruz, \& Rodrigues, 2017). The main changes provided by mineral nutrition, responsible for altering the intensity of diseases, are the thickness of the cell wall and cuticles, the maintenance of soluble compounds inside the cells, such as simple sugars and amino acids, variations in suberization, silicification and lignification of tissues, in the synthesis and accumulation of phenolic compounds (Rodrigues et al., 2017).

Marschner (1995) considers that, in cases of fungal diseases, the protection promoted by balanced mineral nutrition results in the formation of an efficient physical barrier, with inhibition of hyphae penetration or better control of the cytoplasmic membrane permeability. This prevents the release of sugars and amino acids into the intercellular spaces and constitutes a chemical barrier, with the production or formation of phenolic compounds.

The macronutrient calcium was efficient in controlling the disease (Table 3) in the leaves of the lower third and whole plant in both harvests. Calcium activates enzymes related to phosphorus metabolism and acts in the maintenance of the cell wall, in addition to increasing the degree of resistance of plants to pathogens (Taiz \& Zeiger, 2009). Debona, Cruz, and Rodrigues (2017) used foliar calcium applications in wheat (Triticum aestivum L.), and observed a reduction in the blast severity (Pyricularia grisea L.), and that the level of expression of the pathway gene markers of salicylic and jasmonic acid, chitinase, $\beta$-1,3-glucanase, phenylalanine ammonia lyase, peroxidase and polyphenol oxidase was higher in plants with higher doses of calcium.

Junqueira et al. (2011) found positive effects of calcium sulfate mixtures applied via leaf, on the productivity and control of bacterial diseases in passion fruit (Passiflora edulis Sims). The macro and micronutrients present in the syrup, according to the authors, probably changed the thickness of the cell wall and cuticles, helped in the maintenance of soluble compounds inside the cells, such as simple sugars and amino acids, and there were variations in suberization, silicification and lignification of the cells, in the synthesis and accumulation of phenolic compounds or activated lignin synthesis.

Micronutrients ( $\mathrm{Cu}, \mathrm{Mn}, \mathrm{Zn}$ ) also reduced the AUDPC of the disease in both seasons (Table 3), and phytotoxicity did not occur, as Rezende, Tomita \& Usugi (2008) reported phytotoxicity when using copper sulfate to control Erwinia psidii in guavas (Psidium guajava L.). The product, despite controlling the disease, caused severe damage to fruits larger than $31 \mathrm{~mm}$.

NK fertilizer also reduced AUDPC of soybean mildew. For Develash and Sugha (1997), the increase in the amounts of $\mathrm{K}$ in the soil delayed the development of downy mildew (Peronospora destructor (Berk.)) Of the onion. In foliar spraying of fertilizer 03-00-16 (Kendal $\left.{ }^{\circledR}\right)$, Wordell Filho, Martins, and Stadnik (2007) verified a reduction in the AUDPC of onion mildew with weekly spraying of the product.

With regard to A. nodosum algae, it reduced the AUDPC of the disease. Lizzi et al. (1998), demonstrated that the extract of this species of macroalga induces resistance to mildew in pepper (Capsicum annuum L.) and grape 
(Vitis vinifera L.), caused by Phytophtora capsici and Plasmopara viticola, respectively. Subramanian et al. (2011), using the seaweed extract in Arabidopsis thaliana against Pseudomonas syringae pv. tomato and Sclerotinia sclerotiorum concluded that there was a reduction in the severity of both diseases, and that this reduction occurred due to resistance induction, related to the production of jasmonic acid and salicylic acid.

No difference was observed between the control and the fungicide aplications for AUDPC of downy mildew (Table 3). Corroborating with Kowata et al. (2008), who state that the use of fungicides used to control the main leaf diseases of the crop are not efficient to prevent epidemics of this disease. The use of pesticides can cause environmental imbalance and the selection of resistant fungus populations (Thadani \& Rocha, 2019; Tupich et al., 2017).

The products that provided the greatest reduction in the AUDPC of the disease were ASM, micronutrients $(\mathrm{Cu}$, $\mathrm{Mn}, \mathrm{Zn}$ ) and $A$. nodosum being options for strategies for the alternative control of the disease, contributing to the reduction of the pesticides use, reducing the pollution, in addition to contributing to the production of organic soybean.

\section{Conclusion}

In the 2014/2015 harvest the mildew was more severe.

The control of downy mildew by the use of fungicide did not reduce the epidemic. The fungicide was not efficient in the two evaluated seasons.

All of the tested alternative products reduced the mildew severity, especially acibenzolar-S-methyl, micronutrients $(\mathrm{Cu}, \mathrm{Mn}, \mathrm{Zn})$ and $A$. nodosum that have the potential to be inserted in the management of the disease by soybean producers in the region.

\section{References}

Board, J. (2001). Reduced lodging for soybean in low plant population is related to light quality. Crop Science, 41(2), 379-384. https://doi.org/10.2135/cropsci2001.412379x

Callegaro, Á. M., Alves Filho, D. C., Pizzuti, L. Â. D., Segabinazzi, L. R., Brondani, I. L., \& Martini, A. P. M. (2018). Comportamento ingestivo de novilhos mestiços terminados em confinamento alimentados com borra de soja. Ciência Animal Brasileira, 19. https://doi.org/10.1590/1809-6891v19e-28150

Canteri, M. G., Althaus, R., Virgens Filho, J., Giglioti, E. A., \& Godoy, C. V. (2001). SASM Agri: Sistema para Análise e separação de médias em experimentos agrícolas pelos métodos Scot-Knott, Tukey e Duncan. Revista Brasileira de Agrocomputação, 1(2), 18-24. Retrieved from http://www.agrocomputacao.deinfo. uepg.br/dezembro_2001/Arquivos/RBAC_Artigo_03.pdf

Chowdhury, A. K., Srinives, P., Saksoong, P., \& Tongpamnak, P. (2002). RAPD markers linked to resistance to downy mildew disease in soybean. Euphytica, 128(1), 55-60. https://doi.org/10.1023/A:1020635501050

Debona, D., Cruz, M. F., \& Rodrigues, F. A. (2017). Calcium-triggered accumulation of defense-related transcripts enhances wheat resistance to leaf blast. Tropical Plant Pathology, 42(4), 309-314. https://doi.org/ 10.1007/s40858-017-0144-6

Develash, R. K., \& Sugha, S. K. (1997). Factors affecting development of downy mildew (Peronospora destructor) of onion (Allium cepa). Indian Journal of Agricultural Sciences, 67(2), 71-74. https://doi.org/ 10.1016/S0261-2194(96)00056-7

Di Piero, R. M., \& Garda, M. V. (2008). Quitosana reduz a severidade da antracnose e aumenta a atividade da glucanase em feijão comum. Pesquisa Agropecuária Brasileira, 43(9), 1121-1128. https://doi.org/10.1590/ S0100-204X2008000900004

Dong, H., Tan, J., Li, M., Yu, Y., Jia, S., Zhang, C., ... Liu, Y. (2019). Transcriptome analysis of soybean WRKY TFs in response to Peronospora manshurica infection. Genomics, 111(6), 1412-1422. https://doi.org/ 10.1016/j.ygeno.2018.09.014

EMBRAPA (Empresa Brasileira de Pesquisa Agropecuária). (2006). Centro nacional de Pesquisa de Solos. Sistema brasileiro de classificação de solos (p. 306). Rio de Janeiro.

Faccin, A. C. T. M., \& Castillo, R. (2019). A centralidade do complexo-soja na economia brasileira e a manutenção da produção agrícola extravertida: análise da soja em Mato Grosso do Sul. Geosul, 34(71), 111-129. https://doi.org/10.5007/1982-5153.2019v34n71p111 
Fageria, N. K., Filho, M. B., Moreira, A., \& Guimarães, C. M. (2009). Foliar fertilization of crop plants. Journal of Plant Nutrition, 32(6), 1044-1064. https://doi.org/10.1080/01904160902872826

Fontana, J., Capeletti, J., Kalsing, M., Mazaro, S., Gouvea, A., Mari, L., ... Donazzolo, J. (2006). Manejo de doenças na cultura da soja no sudoeste do Paraná na safra 2005/2006. Synergismus Scyentifica, 1(1/4), 150-155. Retrieved from http://revistas.utfpr.edu.br/pb/index.php/SysScy/article/view/2316/1714

Friedrich, L., Lawton, K., Ruess, W., Masner, P., Specker, N., Rella, M. G., M., ... Ryals, J. (1996). A benzothiadiazole derivative induces systemic acquired resistance in tobacco. The Plant Journal, 10(1), 61-70. https://doi.org/10.1046/j.1365-313X.1996.10010061.x

Furtado, E. B., da Rosa Dorneles, K., \& Dallagnol, L. J. (2020). Ação curativa e protetora de compostos orgânicos e inorgânicos no controle de Microsphaera diffusa em soja. Revista de Ciências Agroveterinárias, 19(1), 104-108. https://doi.org/10.5965/223811711912020104

Godoy, C. V., Koga, L. J., \& Canteri, M. G. (2006). Escala diagramática para avaliação da severidade da ferrugem da soja. Fitopatologia Brasileira, 31(1), 63-68. https://doi.org/10.1590/S0100-41582006000 100011

Goel, N., Jaiswal, G., Srivastava, A. K., Paul, P. K., \& Goel, A. (2018). Effect of Drechslera graminea on total soluble proteins and defense enzymes of barley. Journal of Plant Protection Research, 220-226. https://doi.org/10.24425/122936

Hartman, G. L., Rupe, J. C., Sikora, E. J., Domier, L. L., Davis, J. A., \& Steffey, K. L. (2015). Compendium of soybean diseases and pests. St. Paul, MN: American Phytopathological Society. https://oi.org/10.1094/ 9780890544754

Ibanhes Neto, H. F., Freiria, G. H., Costa, D. S. D., Prete, C. E. C., \& Takahashi, L. S. A. (2019). Potencial fisiológico e sanidade de sementes de soja obtidas a partir de manejo orgânico e convencional. Journal of Seed Science, 41(2), 213-223. https://doi.org/10.1590/2317-1545v41n2214881

Inagaki, M. N., Junqueira, C. P., \& Bellon, P. P. (2018). Desafios da produção de soja orgânica como determinante à implantação de seu cultivo para fins comerciais na região oeste do Paraná. Revista Gestão \& Sustentabilidade Ambiental, 7(1), 682-699. https://doi.org/10.19177/rgsa.v7e12018682-6999

Jackson, T. J., Burgess, T., Colquhoun, I., \& Hardy, G. S. (2000). Action of the fungicide phosphite on Eucalyptus marginata inoculated with Phytophthora cinnamomi. Plant Pathology, 49(1), 147-154. https://doi.org/10.1046/j.1365-3059.2000.00422.x

Junqueira, K. P., Faleiro, F. G., Uesugi, C. H., Junqueira, N. T. V., Bellon, G., Santos, E. C. dos, \& Ramos, L. N. (2011). Desempenho agronômico de maracujazeiros tratados com produtos alternativos e fertilizantes foliares. Revista Brasileira de Fruticultura, 33(1), 040-047. https://doi.org/10.1590/S0100-29452011005 000019

Kagale, S., Marimuthu, T., Thayumanavan, B., Nandakumar, R., \& Samiyappan, R. (2004). Antimicrobial activity and induction of systemic resistance in rice by leaf extract of Datura metel against Rhizoctonia solani and Xanthomonas oryzae pv. oryzae. Physiological and Molecular Plant Pathology, 65(2), 91-100. https://doi.org/10.1016/j.pmpp.2004.11.008

Klessig, D. F., Choi, H. W., \& Dempsey, D. M. A. (2018). Systemic acquired resistance and salicylic acid: past, present, and future. Molecular Plant-Microbe Interactions, 31(9), 871-888. https://doi.org/10.1094/ MPMI-03-18-0067-CR

Kobayashi, B. F., \& Amaral, D. R. (2018). Efeito de extratos vegetais de plantas do Cerrado para controle de pinta-preta em tomateiro. Summa Phytopathologica, 44(2), 189-192. https://doi.org/10.1590/0100-5405/ 2194

Kowata, L. S., May-de-Mio, L. L., Dalla Pria, M., \& Santos, H. A. A. D. (2008). Escala diagramática para avaliar severidade de míldio na soja. Scientia Agraria, 9(1), 105-110. https://doi.org/10.5380/rsa.v9i1.10145

Lizzi, Y., Coulomb, C., Polian, C., Coulomb, P. J., \& Coulomb, P. O. (1998). L'algue face au mildiou: Quel avenir? Des résultats de laboratoire très encourageants. Phytoma, la Défense des Végétaux, 508, 29-30. Retrieved from https://pascal-francis.inist.fr/vibad/index.php?action=getRecordDetail\&idt=2367085

Lorencetti, G. A. T., Mazaro, S. M., Potrich, M., Lozano, E. R., Barbosa, L. R., Luckmann, D., \& Dallacort, S. (2015). Produtos alternativos para controle de Thaumastocoris peregrinus e indução de resistência em plantas. Floresta e Ambiente, 22(4), 541-548. https://doi.org/10.1590/2179-8087.066913 
Lorenzetti, E., Stangarlin, J. R., Kuhn, O. J., \& Portz, R. L. (2018). Induction of resistance to Macrophomina phaseolina in soyben treated with rosemary extract. Summa Phytopathologica, 44(1), 45-50. https://doi.org/ 10.1590/0100-5405/176895

Marschner, H. (1995). Functions of mineral nutritions: Magnesium, Calcium, Potassium. Relationships between mineral nutrition and plant diseases and pests. Mineral Nutrition of Higher Plants, 277, 436-460. https://doi.org/10.1016/B978-012473542-2/50013-4

Martinelli, S. S., \& Cavalli, S. B. (2019). Alimentação saudável e sustentável: Uma revisão narrativa sobre desafios e perspectivas. Ciência \& Saúde Coletiva, 24, 4251-4262. https://doi.org/10.1590/1413-81232018 2411.30572017

Miranda, M. L. D., \& Pires-Zottarelli, C. L. A. (2012). Oomicetos do Parque Estadual da Serra da Cantareira, São Paulo, SP, Brasil. Hoehnea, 39(1), 95-112. https://doi.org/10.1590/S2236-89062012000100005

Moura, G. S., Franzener, G., Stangarlin, J. R., \& Schwan-Estrada, K. R. F. (2014). Atividade antimicrobiana e indutora de fitoalexinas do hidrolato de carqueja [Baccharis trimera (Less.) DC.]. Revista Brasileira de Plantas Medicinais, 16(2), 309-315. https://doi.org/10.1590/1983-084X/10_121

Müller, M. A., Klosowski, A. C., Dalla Pria, M., Mazaro, S. M., \& De Mio, L. L. M. (2019). Bacillus thuringiensis Combined With Fungicide Applications in the Management of Soybean Leaf Diseases. Journal of Agricultural Science, 11(13). https://doi.org/10.5539/jas.v11n13p226

Nawrocka, J., Małolepsza, U., Szymczak, K., \& Szczech, M. (2018). Envolvimento de componentes metabólicos, compostos voláteis, proteínas PR e fortalecimento mecânico na proteção multicamada de plantas de pepino contra Rhizoctonia solani ativada por Trichoderma atrovirida TRS25. Protoplasma, 255(1), 359-373. https://doi.org/10.1007/s00709-017-1157-1

Rezende, A. M. F. A., Tomita, C. K., \& Uesugi, C. H. (2008). Fungicidas cúpricos, cloretos de benzalcônio e composto bioativo liquído (Bokashi): fitotoxicidade e controle da seca dos ponteiros causada por Erwinia psidii em goiabeiras. Tropical Plant Pathology, 33(4), 288-294. https://doi.org/10.1590/S1982-56762008 000400005

Ritchie, S. W., Hanway, J. J., Thompson, H. E., \& Benson, G. O. (1997). How a soybean plant develops (Special Report 53, p. 20). Ames, Iowa State University of Science and Technology.

Rodrigues, F. Á., Rios, J. A., Debona, D., \& Aucique-Pérez, C. E. (2017). Pyricularia oryzae-wheat interaction: physiological changes and disease management using mineral nutrition and fungicides. Tropical Plant Pathology, 42(3), 223-229. https://doi.org/10.1007/s40858-017-0130-z

Shaner, G., \& Finney, R. E. (1977). The effect of nitrogen fertilization on the expression of slow-mildewing resistance in Knox wheat. Phytopathology, 67(8), 1051-1056. https://doi.org/10.1094/Phyto-67-1051

Silva, O. C., Santos, H. A. A., Dalla Pria, M., \& May-De Mio, L. L. (2011). Potassium phosphite for control of downy mildew of soybean. Crop Protection, 30(6), 598-604. https://doi.org/10.1016/j.cropro.2011.02.015

Silva, O. C., Santos, H. A., Deschamps, C., Dalla Pria, M., \& May De Mio, L. L. (2013). Fontes de fosfito e acibenzolar-S-metílico associados a fungicidas para o controle de doenças foliares na cultura da soja. Tropical Plant Pathology, 38(1), 72-77. https://doi.org/10.1590/S1982-56762013000100012

Subramanian, S., Sangha, J., Gray, B., Singh, R., Hiltz, D., Critchley, A., \& Prithiviraj, B. (2011). Extracts of the marine brown macroalga, Ascophyllum nodosum, induce jasmonic acid dependent systemic resistance in Arabidopsis thaliana against Pseudomonas syringae pv. tomato DC3000 and Sclerotinia sclerotiorum. European Journal of Plant Pathology, 131, 237-248. https://doi.org/10.1007/s10658-011-9802-6.

Taiz, L., \& Zeiger, E. (2009). Fisiologia vegetal (4th ed., p. 820). Porto Alegre: Artmed.

Thadani, R. M., \& Rocha, A. C. B. (2019). A opção do produtor Brasileiro produzir soja não geneticamente modificada pode ser uma vantagem estratégica/The Brazilian producer's option to produce non-genetically modified soybeans may be a strategic advantage. Brazilian Journal of Development, 5(7), 9969-9994. https://doi.org/10.34117/bjdv5n7-164

Tormen, N. R., da Silva, F. D., Debortoli, M. P., Uebel, J. D., Fávera, D. D., \& Balardin, R. S. (2012). Deposição de gotas no dossel e controle químico de Phakopsora pachyrhizi na soja. Revista Brasileira de Engenharia Agrícola e Ambiental, 16(7), 802-808. https://doi.org/10.1590/S1415-43662012000700015 
Tupich, F. L. B., Fantin, L. H., Silva, A. L. D., \& Canteri, M. G. (2017). Impacto do controle do mofo-branco com fluazinam na produtividade da soja no Sul do Paraná: Metanálise. Summa Phytopathologica, 43(2), 145-150. https://doi.org/10.1590/0100-5405/168479

USDA (United States Department of Agriculture). (2019). World Agricultural Production. Retrieved from https://apps.fas.usda.gov/psdonline/circulars/production.pdf

Vasconcelos, I. M., Maia, A. A., Siebra, E. A., Oliveira, J. T., Carvalho, A., Melo, V. M., \& Castelar, L. I. D. M. (2001). Nutritional study of two Brazilian soybean (Glycine max) cultivars differing in the contents of antinutritional and toxic proteins. The Journal of Nutritional Biochemistry, 12(1), 55-62. https://doi.org/ 10.1016/S0955-2863(00)00148-0

Wordell Filho, J. A., Martins, D. A., \& Stadnik, M. J. (2007). Aplicação foliar de tratamentos para o controle do míldio e da podridão-de-escamas de bulbos de cebola. Horticultura Brasileira, 25(4), 544-549. https://doi.org/10.1590/S0102-05362007000400010

Zuntini, B., Alvarez, R. D. C. F., Theodoro, G. D. F., \& Zuffo, A. M. (2019). Effect of adding fungicide to mixtures of triazoles and strobilurins in the control of downy mildew and Asian soybean rust. Pesquisa Agropecuária Tropical, 49. https://doi.org/10.1590/1983-40632019v4953688

\section{Copyrights}

Copyright for this article is retained by the author(s), with first publication rights granted to the journal.

This is an open-access article distributed under the terms and conditions of the Creative Commons Attribution license (http://creativecommons.org/licenses/by/4.0/). 